\title{
RANKING DELAY, COST, QUALITY FACTORS FOR PROJECT SUCCESS IN REAL ESTATE COMPANIES
}

\author{
Ajit Pal Singh (PhD Research Scholar) ${ }^{1} \&$ Rajwinder Singh ${ }^{2}$
}

\begin{abstract}
Real estate construction delays, cost escalation, and poor quality of construction can be defined as the late completion of projects compared to the planned schedule, cost spent within budget, and according to quality specification. Real estate construction delays, cost control, and poor quality of construction can be minimized only when their causes are identified. The aim of this research study was to identify and rank the most important factors and items causing of construction delays, cost escalation, and poor quality of construction related reasons in Addis Ababa (Ethiopia). A structured questionnaire five points Likert scaled based was adopted in this study; 750 questionnaires were distributed to employees working in real estate companies in Addis Ababa city. The ordinal data were analyzed by the Pearson productmoment correlations coefficients, which was used to check the relationship among factors and relative important index method, which was used to rank the factors and items by using relative importance index. Pearson product-moment correlations coefficients research findings revealed that there is no positive strong relationships among three factors i.e., delay, cost increasing, and poor quality in real estate construction projects. Also relative importance index shows that cost increasing factor $(0.680)$ was found to be most obstacles followed by delay in project completion factor $(0.627)$. The findings of this research study would be valuable for all real estate construction professionals involved in the real estate companies.
\end{abstract}

Keywords-Project management, Delay, Cost, Quality, Real estate companies

\section{INTRODUCTION}

Construction plays a major role in the development of any nation and was considered one of the major indicators for measuring the economic growth of countries (Alzahrani \& Emsley, 2013). The construction industry has unique characteristics, which include the construction process, project management knowledge areas and project management process group.

According to Anbari (1985) projects and project management can trace their roots to major project such as the pyramids, the Great Wall of China, Roman roads and viaducts, and Greek architecture. Whereas, modern project management can be traced to the 1950s and the 1960s, with major project such as the Polaris project, space exploration, highways, nuclear power plants, and defense systems. Since then, project management has been growing rapidly and strengthened by new applications of project management in engineering, construction, information technology, pharmaceuticals, and government, as well as a better understanding of the effectiveness of project management for increasing resource productivity and producing successful project outputs and strategic outcomes (Anbari, 2010).

\section{A. Project}

Projects are playing major role in the economic development of a country. During planning of economy of the country large amount of money is to be invested in projects related to industry, construction, minerals, power, transportation, irrigation, education etc. with a view to improve the socio-economic conditions of the people. These projects are designed and implemented with the plan of well-organized management, earning adequate return to provide for future development with their own resources.

Professionals, expert, and practitioner have stated that project management is a vital strategic view. It provides entities with powerful set of tools that develop their ability to apply managerial functions to accomplish specific organizational goals. Project management is a results-oriented management style that places a quality on building collaborative relationships among diverse cast of characters. Exciting openings await people skilled in project management areas (Larson \& Grey, 2011).

Different researchers give various definitions for a project. Their definition depends on their areas of research studies and the point of view that each researcher used. But to have comprehensive understanding of a project, it is better to refer different definitions of a project. According to Oxford Dictionaries (2016) in modern business and science, a project is an individual or joint enterprise, possibly involving research or design that is carefully planned, usually by a project team, to achieve a particular aim. A project is a set of interrelated tasks to be executed over a fixed time period and within certain cost and other limitations (BusinessDictionary.com). According to PMI (2013) project is a temporary endeavor undertaken to create a unique product, service, or result.

Larson and Grey (2011) stated: 'Like most organizational effort, the major goal of a project is to satisfy a customer's need. Beyond this fundamental similarity, the characteristics of a project help differentiate it from other endeavors of the organization". This definition was given based on two key characteristics of project. All projects are temporary and undertaken

\footnotetext{
${ }^{1}$ Shri Jagdishprasad Jhabarmal Tibrewala University, Jhunjhun, Rajasthan, India

${ }^{2}$ School of Management Studies, Punjabi University, Patiala, Punjab, India
} 
to create a product, service, or result that is unique. These two simple concepts create a work environment that mandates different management approach from that used by an operations manager, whose work is oriented toward continuous improvement of existing processes over longer periods of time.

Accordingly, Modesto and Tichapondwa (2009) define project as initiative to bring about change in order to achieve specific objectives, within a timescale, in a given context with normally allocated budget. Verzuh (2005) stated that: "we live in a world where change and the rate of change is constantly increasing. In order to survive and prosper, organizations need to continually modify their products and services. Projects are the means by which these innovations are affected. Greater change = more innovations $=$ more projects."

Many other researchers and books prefer to define and explain project by describing the common characteristics of projects instead of giving a direct definition so that anyone can define project by integrating these features of projects. Different scholars provide the unique features of projects. Nicholas and Steyn (2008) provide comprehensive characteristics of projects. The following section is the discussion on these characteristics.

\section{B. Characteristics of a Project}

Regardless of specific features of particular projects, below are some common characteristics forwarded by Nicholas and Steyn (2008) for all projects:

- A project involves a single, definable purpose and well-defined end-items, deliverables, or results, specified in terms of cost, schedule, and performance requirements. Larson and Grey (2011) stated that this singular purpose is often missing in daily organizational life where employees carry out repetitive operations daily.

- Every project is unique, a one-time activity, something different than was done previously and never to be exactly repeated again. Lock (2001) discussed that the principal identifying characteristic of any project is its novelty and stepping into the unknown, fraught with risk and uncertainty. No two projects are ever exactly identical, and even a repeated will differ from its predecessor, administrative or physical aspects. In a "routine" project such as home construction, variables such as terrain, access, zoning laws, labor market, public services, and local utilities make it unique.

- Projects are temporary activities consisting of an ad hoc organization of personnel, resources, and facilities assembled to accomplish a objective within a scheduled time frame; once the specified objective is achieved, the ad hoc activities are disbanded.

- Projects cut across organizational and functional lines because they need skills and multiple talents, professions, and organizations. Larson and Grey (2011) stated that instead of working in separate offices under separate managers, all project team members should work closely together under the guidance of a project manager to complete a project.

- Given that each project is unique involving unfamiliarity, risk and encompass new processes and for the organization undertaking it, possess significant elements of uncertainty and risk.

- The organization usually has something at risk while doing a project. The work calls for special analysis because failure would put in danger the organization objectives.

- A project is the process of working to achieve an objective; during the process, projects pass through project life cycle. The tasks, people, organizations, and other resources involved in the project change as the project moves from one phase to the next.

\section{Classification of Projects}

The scope, size, type, location, technology/processes, and speed are normally the factors which determine the effort needed in executing a project. Project can be classified under different heads, some of which are shown in Figure 1 (http://www.ddegjust.ac.in).

Projects can be classified under different headings such as based on type of works that projects involve, based on size (duration) of projects, and so on. Lock (2001) classified projects into four main headings based on type of works that projects involve as the following.

(1) Civil Engineering, Construction, Petrochemical, Mining and Quarrying Projects

These projects are characterized by on site activities, remote from the contractors' head office which incur special risks, and involves massive capital investment. They deserve rigorous management of time, cost, and quality. If the projects are extralarge, they will involve several contractors working together as joint venture or in a form of other means, which makes the projects more complicated. Barrie and Paulson (1992) defined that the construction industry is divided into four categories; residential construction (i.e., single family homes, multi unit town houses, garden apartments, high-rise apartments and condominiums), building construction, heavy engineering construction and industrial construction.

(2) Manufacturing Projects

Upon establishment of factories for producing goods, projects are often conducted. Different additional projects will also be executed after the establishment of a factory for different purposes such as new product development. These postestablishment projects are called manufacturing projects. 


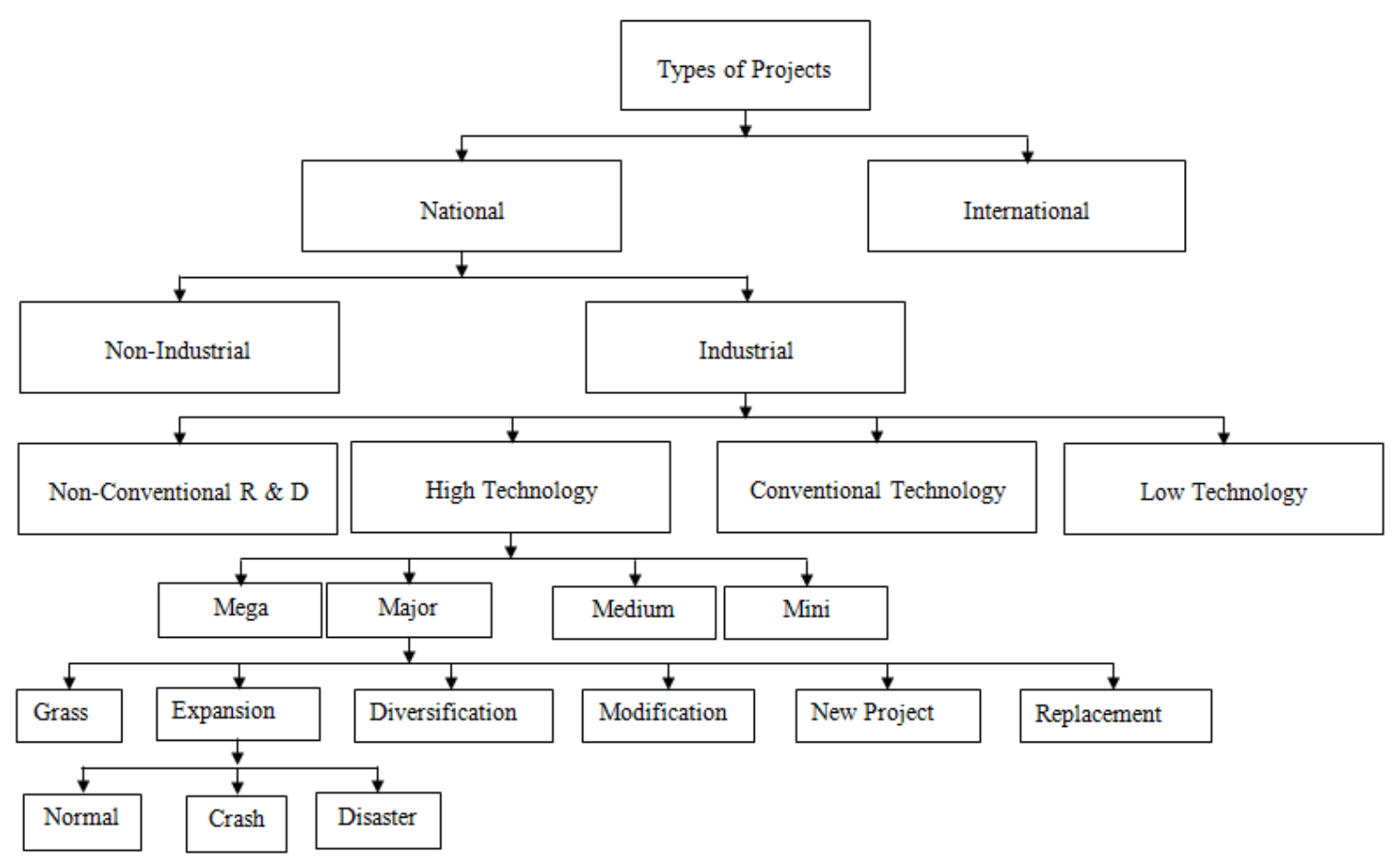

Figure 1: Classification of Project (Lock, 2001)

(3) Management Projects

Regardless of the size of a company, it will run at least few projects throughout its lifespan. These projects are required by a company in different situations such as on plant or service center relocation, on restructuring of a system and organization, in research and development, for feasibility studies, for executing special trainings, to plan and conduct celebrations, etc.

(4) Research Projects

These projects are independent research projects which consume huge amount of funds and lasts for many years. They assume high level of risks so that it becomes difficult or impossible to define end results. These projects require effective time and cost management.

Real estate projects involve the construction of houses for selling purpose. They also require huge capital investment with longer time and quality demands. Accordingly, they come under the first category of projects.

\section{Project Management}

PMI (2013) defines project management as an application of knowledge, skills, tools, and techniques to project activities to meet the project requirements. Similarly, Chandra (2017) define project management as an organized venture for managing projects, involves scientific application of modern tools and techniques in planning, financing, implementing, monitoring, controlling and coordinating unique activities or task produce desirable outputs in accordance with the determined objectives within the constraints of time and cost. This Chandra's definition of project management is used as operational meaning in this research study. Project management is accomplished through the appropriate application and integration of the different logically grouped project management processes, which are categorized into five process groups. According to PMI (2013), these five process groups are: initiating, planning, executing, monitoring and controlling, and closing.

McNamara (2002) stated that project management is carefully planned and organized efforts to accomplish a specific one-time effort, for example, construct a building. Project management includes developing a project plan, which includes defining project goals and objectives, specifying tasks along with careful controls to ensure the plan is being managed according to plan, what resources are needed, and associating budgets and timelines for completion. Project management generally follows major phases, including feasibility study, project planning, implementation, evaluation and support. Heerkens (2012) stated: "The project management process calls for the creation of a small organizational structure, which is often a microcosm of the larger organization. Once the team has produced the desired outcome, the process then calls for the decommissioning of that small organizational structure."

\section{PROJECT SUCCESS - TIME, COST, AND QUALITY FACTORS}

According to Muller and Jugdev (2012) there is no clear definition exists and stresses the need for measurable constructs of project success. According to Wit (1988) projects are a unique and temporary organization and vary in size, context and complexity. Accordingly, a criterion for measuring the success of a project varies (Mir \& Pinnington, 2014) and a common 
definition of project success and ways to measure it is therefore unlikely (Westerveld, 2003). Further Mir and Pinnington (2014) stated that the task is further obstructed by different interpretations and criteria of success from different stakeholders.

Rockart (1982) coined the term-critical success factor and as those relatively small numbers of essentially important issues, which made the difference between success and failure. He explained that organizations should focus their attention and resources on these issues in order to achieve success. Cooke-Davies (2002), Sanvido, Grobler, Parfitt, Guvenis, and Coyle (1992), and Tiong (1992) agreed to a view whereby they defined critical success factors as those factors which are important for the project stakeholders to achieve their project goals.

Cheong and Mustaffa (2017) research study outlined the development trend of project success measurement globally and locally. Cheung, Suen, and Cheung (2004) identified project performance grouping such as people, cost, time, quality, safety and health, environment, client satisfaction, and communication. According to Freeman and Beale (1992) and Iyer (1996) schedule, cost, quality, safety' and no-disputes are the important project evaluation criteria.

Pinto and Slevin (1987) described a process used to determine ten vital success factors that are felt to be foretelling of successful project management. The research study has provided the basis for developing a behavioral instrument to be used as a diagnostic for assessing the status of any project as determined by the model.

Project management success is measured mostly according to the traditional "iron-triangle" of time, cost, and quality (Shenhar \& Dvir, 2007; Pinto \& Slevin, 1988; Morris \& Hough, 1987). All projects are controlled to a time outline during which they are to be completed. No projects are intended to continue forever. Thus, one of the basic requirements that control project management and determine its success is whether it is completed on as per stated schedule (Pinto, 2013).

Also all projects are constrained to a restricted budget, no organization has unlimited resources to spend on projects. Project also struggle for resources between each other. In order to use resources economically projects must stick to approved budget. Therefore, the second requirement that control project management is whether it is completed within budget guidelines or not (Pinto, 2013). Again all projects are produced to meet to some form of technical requirement determined at project initiation phase. Hence, measuring success equals determining to what extent the project fulfills the requirement (Pinto, 2013).

Niazi and Painting (2017) identified the significant factors that lead to construction cost overruns in Afghanistan. Results revealed that the key critical causes result in construction cost overruns in Afghanistan are corruption, delay in progress payment by owner, difficulties in financing project by contractors, security, change the order by the owner during construction and market inflation. Al-Hazim, Salem, and Ahmad (2017) study investigated the factors that may cause overrun of the planned cost, allocated resources and scheduled time of infrastructure engineering projects. The results revealed that the top factors terrain and weather conditions are causing completion delay and cost overrun in infrastructure projects in Jordan.

Senouci, Ismail, and Eldin (2016) investigated cost overruns and delays in Qatari public construction projects. Wanjari and Dobariya (2016) identified top three factors affecting cost overruns such as price escalation of raw material, delay in planned activity and lack of co-ordination between construction parties which could be significantly responsible for cost overrun of construction project in India.

Mukuka, Aigbavboa, and Thwala (2015) assessed the effects of construction projects schedule overruns in the construction industry. The results revealed that the major effects of construction projects schedule overruns are due to addition of time, cost overruns, loss of profit, disputes, poor quality of work, stress to the client, hastening losses, bad reputation with contraction team, claims and delay in getting profit by the client were in Gauteng, South Africa.

Chai and Yusof (2015) defined and reclassify delay in housing delivery system and it is found that institutional delay is the major contributor to housing delay in Malaysia. Rahman, Memon, and Karim (2013) focused on investigated the effect of various factors on budget overrun in construction projects undertaken using management procurement method in Malaysia.

Desai and Desale (2013) presented list of construction delays causes retrieved from literature. Sweis, Sweis, Rumman, Hussein, and Dahiyat (2013) identified the factors i.e., governmental delay, severe weather conditions and design changes that have major roles in affecting the projects' cost and these factors can be alleviated in the future. Ismail, Rahman, and Memon (2013) studied the factors affecting time and cost overruns throughout life cycle of construction projects. However, all the research studies shall not be produced but the contributions of many researchers to identify factors affecting project management strategies in terms of project success, time, cost, and quality are shown in Appendix-A.

\section{RESEARCH METHODOLOGY}

Primary data collection is done by a structured designed questionnaire based on five point ordinal measures Likert scale representing strongly agreed $=5$ and strongly disagree $=1$ was adopted in this research study to investigate the reasons related to delay in project completion, project cost increasing, and poor quality of construction in real estate construction projects in the Addis Ababa city (Ethiopia). The questionnaires survey was used due most speedy, cheaper and economical methods for collecting a large amount of data in a short period.

Questionnaire was randomly distributed to 750 employees working in real estate companies in Addis Ababa city (Ethiopia). A total of 737 questionnaires were received, yielding $87.24 \%$ response rate. 641 correctly filled questionnaires were adequate for analysis and reporting the findings of this research study (Miller, 1991). Questionnaire are coded and analyzed further for correlation analysis and relative importance index methods by using SPSS-20 version. A total of three factors consisting of 44 items were identified by previous studies as shown in Appendix-A. 
A pilot study was also conducted by distributing the 50 questionnaires to experts, managers in real estate compaines, and advisor to identify ambiguous questions/items and to test the techniques used to collect data. Pilot questionnaire study results were reviewed and minor adjustments were made accordingly a final questionnaire is produced.

Pearson product-moment correlation coefficient (r) is generally used method for measuring the degree of relationship between two variables. It is assumed that there is linear relationship between the two variables and the two variables are casually related which means that one of the variables is independent and the other one is dependent. Moreover, a large number of independent causes are operating in both variables to produce a normal distribution (Kothari \& Garg, 2014). The present research study applied Pearson product-moment correlations coefficients ( $r$ ) to determine the relationship between project management knowledge areas and real estate project success.

The Pearson product-moment correlations coefficients (r) matrix obtained for the five interval-scaled variables is shown in Table 1.

Table 1: Guidelines to Interpret Pearson Product-Moment Correlations Coefficients (r)

\begin{tabular}{|l|l|}
\hline Strength of Association & Pearson Correlation Coefficient (r) \\
\hline Weak & $0-0.29$ \\
\hline Moderate & $0.30-0.49$ \\
\hline Strong & $0.50-1.00$ \\
\hline
\end{tabular}

Source: Pallant, 2010; Cohen, 1988

According to Kothari and Garg (2014) the value of the Pearson product-moment correlations coefficients (r) should lie between +1 and -1 . A positive values of Pearson product-moment correlations coefficients ( $r$ ) indicates a positive correlation between the two variables (i.e., changes in both variables take place in the statement direction), whereas negative values of Pearson product-moment correlations coefficients (r) indicate negative correlation (i.e., changes in the two variables taking place in the opposite directions). Whereas, a zero value of Pearson product-moment correlations coefficients ( $r$ ) indicates that there is no association between the two variables. The value of Pearson product-moment correlations coefficients ( $r$ ) nearer to +1 or -1 indicates high degree of correlation between the two variables.

To measure attitudes with respect to the questionnaire factors and items, the relative importance index technique was used. The relative index technique has been more used in construction research studies for measuring attitudes with respected to questionnaires factors and items under research study.

The relative importance index was computed based on the following question (1).

Relative importance of index (RII) $=\frac{\sum \text { Weights }}{\mathrm{A} \times \mathrm{N}}=\frac{1 \mathrm{n}_{1}+2 \mathrm{n}_{2}+3 \mathrm{n}_{3}+4 \mathrm{n}_{4}+5 \mathrm{n}_{5}}{5 \times 641}$

Where,

$\mathrm{W}=$ Weight given to each factor by the respondent (Likert scale ranging from 1-5)

$\mathrm{n}_{1}=$ Number of respondents indicating "strongly agree", $\mathrm{n}_{2}$ is the number of respondents indicating "disagree", $\mathrm{n}_{3}$ is the number of respondents indicating "netural", $\mathrm{n}_{4}$ is the number of respondents indicating "agreed", $\mathrm{n}_{5}$ is the number of respondents indicating "strongly agreed"

A = Highest weight (i.e., 5 in this case)

$\mathrm{N}=$ Total number of respondents (i.e., 641 in this case)

The relative importance index ranges from 0 to 1 (Naoum, 2007), higher the value of relative importance index for factor and item more important was the reasons for delay in project completion, reasons for project cost increasing, and reasons related to poor quality of construction in real estate companies project. These ranking make it possible to compare the relative importance of the factors. The relative importance index scale used for relative importance index analysis is shown in Table 2.

Table 2: Relative Importance Index (RII) Scale

\begin{tabular}{|l|l|}
\hline RII Scale & Impact \\
\hline $0.00-0.20$ & Not critical \\
\hline $0.21-0.40$ & Fairly critical \\
\hline $0.41-0.60$ & Average critical \\
\hline $0.61-0.80$ & Very critical \\
\hline $0.81-1.00$ & Extremely critical \\
\hline
\end{tabular}

Source: Bhirud \& Vasant (2015)

\section{DATA COLLECTION AND ANALYSIS}

A. Correlation between Project Delay, Cost, Quality and Project Success

This research study applied Pearson product-moment correlations coefficients (r) to determine the effects of project delay, cost, and quality on real estate project success. 
The strength of relationship between (i) reasons for delay in project completion (PDC), (ii) reasons for project cost increasing (PCI), (iii) reasons related to poor quality of construction (PQC), and dependent variable project success (PS) are shown in Table 3.

Table 3 result reflects that all the independent variables such as reasons for delay in project completion (PDC) has a positive correlation, reasons for project cost increasing (PCI) has negative correlation, reasons related to quality of construction (PQC) has positive correlation with the dependent variable (i.e., project success).

Table 3: Product-Moment Correlations Coefficients (r) between Independent and Dependent Variables, N=641

\begin{tabular}{|l|l|l|l|l|l|l|l|}
\hline & SD & & PDC & PCI & PQC & PDCQ & PS \\
\hline \multirow{2}{*}{ PDC } & \multirow{2}{*}{0.211} & r & 1 & & & & \\
\cline { 3 - 8 } & & Sig. & & & & & \\
\hline \multirow{2}{*}{ PCI } & \multirow{2}{*}{0.668} & $\mathrm{r}$ & $0.378^{* *}$ & 1 & & & \\
\cline { 3 - 9 } & & Sig. & 0.000 & & & & \\
\hline \multirow{2}{*}{ PQC } & \multirow{2}{*}{0.166} & $\mathrm{r}$ & -0.003 & 0.037 & 1 & & \\
\cline { 3 - 9 } & & Sig. & 0.936 & 0.347 & & & \\
\hline \multirow{2}{*}{ PDCQ } & \multirow{2}{*}{0.265} & $\mathrm{r}$ & $0.582^{* *}$ & $0.948^{* *}$ & $0.239^{* *}$ & 1 & \\
\cline { 3 - 9 } & & Sig. & 0.000 & 0.000 & 0.000 & & \\
\hline \multirow{2}{*}{ PS } & \multirow{2}{*}{0.654} & $\mathrm{r}$ & 0.010 & $-0.184^{* *}$ & 0.019 & $-0.147^{* *}$ & 1 \\
\cline { 3 - 8 } & & Sig. & 0.798 & 0.000 & 0.633 & 0.000 & \\
\hline
\end{tabular}

**. Correlation is significant at the 0.01 level (2-tailed).

Note: SD-Standard deviation, r-Pearson correlation coefficient, Sig.-Significance at 2-tailed, PDCQ-Project delay, cost, and quality, Independent variables-Delay in project completion (PDC), project cost increasing (PCI), Project quality of construction (PQC), and dependent variable-project success (PS)

Source: Computation based on data gathered from author's field work

(i) Delay in Project Completion (PDC) and Project Success (PS)

The relationship between delay in project completion (PDC) and project success was investigated using Pearson productmoment correlation coefficient (r). There was a very weak, positive correlation between the two variables (Table 2 ), $r=0.010, n$ $=641, \mathrm{p}>.01$ (statistically not significant), reflecting that hypothesis one is rejected (H1: Delay in real estate construction projects has positive strong relationship with project success). Therefore, alternative hypothesis was accepted i.e., delay in real estate construction projects has no positive strong relationship with project success.

(ii) Project Cost Increasing (PCI) and Project Success (PS)

The relationship between project cost increasing $(\mathrm{PCI})$ and project success was investigated using Pearson product-moment correlation coefficient $(\mathrm{r})$. There was a strong, negative correlation between the two variables (Table 2), $\mathrm{r}=-.814, \mathrm{n}=641, \mathrm{p}<$ .01 (statistically significant), reflecting that hypothesis two is rejected (H2: Cost increasing in real estate construction projects has positive strong relationship with project success). Therefore, alternative hypothesis was accepted i.e., cost increasing in real estate construction projects has no positive strong relationship with project success.

Since the sign of the Pearson product-moment correlations coefficients (r) value is negative (less than 0), the relationship is indirect, indicating that both variables move in the opposite direction. If one variable increases (reasons of project cost increasing-PCI), the other variable decreases (project success-PS) with the same magnitude, and vice versa. It means as the reasons of project cost increasing (PCI) increases, there is a strong likelihood that project success (PS) will also decrease.

(iii) Poor Quality of Construction (PQC) and Project Success (PS)

The relationship between poor quality of construction (PQC) and project success was investigated using Pearson productmoment correlation coefficient ( $\mathrm{r}$ ). There was a very weak, positive correlation between the two variables (Table 2 ), $r=0.019, \mathrm{n}$ $=641, \mathrm{p}>.01$ (statistically not significant), reflecting that hypothesis three is rejected (H3: Poor quality of construction in real estate construction projects has positive strong relationship with project success). Therefore, alternative hypothesis was accepted i.e., Poor quality of construction in real estate construction projects has no positive strong relationship with project success.

\section{B. Ranking Reasons for Delay, Cost, and Quality related Problems Factors}

There are 20 items for reasons for delay in project completion factor, 16 items for reasons for project cost increasing factor, and 8 items are related to poor quality of construction factor. The level of importance of each factor and item were established by comparing relative importance index for each of the factor and item and accordingly ranking has been done for each factor and item. Table 4 shows a summary of the relative importance index and the rank for each factor and item.

(i) Reasons for Delay in Project Completion

The second most significant factor is delays in project completion in real estate residential projects to be successful. Under this factor, item cost variations is there for materials and equipments used for construction time to time. Table 4 shows that respondents ranked the materials and equipments cost variations, and lack of foreign currency exchange as the first and second 
of the most influential cause (0.721 and 0.717: very critical) responsible for project delay among the sixteen items respectively. Followed by materials purchased from abroad countries as third, materials unavailability in local market as fourth, and materials unavailability on time as fifth $(0.697,0.671$, and 0.658 : very critical). These results agrees with the findings of several researches conducted in different countries to evaluate the most significant causes of project delays as shown in Appendix-A.

Table 4: Relative Importance Index and Ranking factors and Items, N = 641

\begin{tabular}{|c|c|c|c|c|c|c|c|c|c|}
\hline \multirow[t]{2}{*}{ Factors/Items } & \multicolumn{5}{|c|}{$\begin{array}{c}\text { Importance } \\
\text { (Five Point Likert Scale) }\end{array}$} & \multirow[t]{2}{*}{ Weight } & \multirow[t]{2}{*}{ RII } & \multirow[t]{2}{*}{ Ranking } & \multirow[t]{2}{*}{ Critical } \\
\hline & 1 & 2 & 3 & 4 & 5 & & & & \\
\hline \multicolumn{7}{|c|}{ Reasons for Delay in Project Completion (PDC) } & 0.627 & 2 & Very Critical \\
\hline 1. Materials, equipments cost variations & 8 & 92 & 164 & 259 & 118 & 2310 & 0.721 & 1 & Very Critical \\
\hline 2. Lack of foreign currency exchange & 11 & 72 & 217 & 214 & 127 & 2297 & 0.717 & 2 & Very Critical \\
\hline 3. Materials coming from aboard & 8 & 86 & 233 & 214 & 100 & 2235 & 0.697 & 3 & Very Critical \\
\hline 4. Materials unavailability local market & 12 & 125 & 202 & 226 & 76 & 2152 & 0.671 & 4 & Very Critical \\
\hline 5. Materials unavailability time & 16 & 144 & 199 & 203 & 79 & 2108 & 0.658 & 5 & Very Critical \\
\hline 6. Collection amount house owner & 14 & 116 & 293 & 162 & 56 & 2053 & 0.641 & 6 & Very Critical \\
\hline 7. Numbers project going & 16 & 145 & 258 & 165 & 57 & 2025 & 0.632 & 7 & Very Critical \\
\hline 8. Lack of coordination & 18 & 169 & 227 & 164 & 63 & 2008 & 0.627 & 8 & Very Critical \\
\hline 9. Skilled manpower shortage & 25 & 164 & 230 & 158 & 64 & 1995 & 0.622 & 9 & Very Critical \\
\hline 10. Design change & 17 & 172 & 272 & 132 & 48 & 1945 & 0.607 & 10 & Average Critical \\
\hline 11. Clearing wastes site & 35 & 147 & 310 & 131 & 32 & 1943 & 0.606 & 11 & Average Critical \\
\hline 12. Time techniques & 51 & 133 & 241 & 202 & 14 & 1918 & 0.598 & 12 & Average Critical \\
\hline 13. Project location & 21 & 194 & 273 & 114 & 39 & 1879 & 0.586 & 13 & Average Critical \\
\hline 14. Budget insufficient & 68 & 202 & 189 & 167 & 15 & 1782 & 0.556 & 14 & Average Critical \\
\hline 15. Finance insufficient & 94 & 177 & 207 & 138 & 25 & 1746 & 0.545 & 15 & Average Critical \\
\hline 16. Machinery unavailability & 67 & 216 & 212 & 130 & 16 & 1735 & 0.541 & 16 & Average Critical \\
\hline \multicolumn{7}{|l|}{ Reasons for Project Cost Increasing (PCI) } & 0.680 & 1 & Very Critical \\
\hline 1. Materials price fluctuating & 8 & 48 & 159 & 245 & 180 & 2461 & 0.768 & 1 & Very Critical \\
\hline 2. Cost machinery fluctuating & 8 & 56 & 174 & 217 & 186 & 2440 & 0.761 & 2 & Very Critical \\
\hline 3. Transportation cost fluctuating & 6 & 54 & 189 & 221 & 171 & 2420 & 0.755 & 3 & Very Critical \\
\hline 4. Tendering method & 16 & 84 & 156 & 175 & 210 & 2402 & 0.749 & 4 & Very Critical \\
\hline 5. Machinery maintenance cost & 8 & 54 & 200 & 222 & 157 & 2389 & 0.745 & 5 & Very Critical \\
\hline 6. Cost labor fluctuating & 12 & 70 & 185 & 192 & 182 & 2385 & 0.744 & 6 & Very Critical \\
\hline 7. Interest rates bankers & 13 & 87 & 189 & 180 & 172 & 2334 & 0.728 & 7 & Very Critical \\
\hline 8. Monopoly suppliers & 11 & 119 & 148 & 212 & 151 & 2296 & 0.716 & 8 & Very Critical \\
\hline 9. Currency exchange & 10 & 110 & 163 & 244 & 114 & 2265 & 0.707 & 10 & Very Critical \\
\hline 10. Inflationary pressure & 13 & 105 & 164 & 243 & 116 & 2267 & 0.707 & 9 & Very Critical \\
\hline 11. Local production raw materials & 20 & 125 & 184 & 220 & 92 & 2162 & 0.675 & 11 & Very Critical \\
\hline 12. Estimation methods & 30 & 142 & 213 & 155 & 101 & 2078 & 0.648 & 12 & Very Critical \\
\hline 13. Project financing & 12 & 150 & 229 & 184 & 66 & 2065 & 0.644 & 13 & Very Critical \\
\hline 14. Poor productivity & 25 & 135 & 248 & 188 & 45 & 2016 & 0.629 & 14 & Very Critical \\
\hline 15. Number of competitors & 13 & 131 & 305 & 141 & 51 & 2009 & 0.627 & 15 & Very Critical \\
\hline 16. Construction cost data & 25 & 178 & 220 & 163 & 55 & 1968 & 0.614 & 16 & Very Critical \\
\hline 17. Financial control site & 24 & 188 & 224 & 156 & 49 & 1941 & 0.606 & 11 & Average Critical \\
\hline 18. Duration contract period & 17 & 170 & 278 & 133 & 43 & 1938 & 0.605 & 18 & Average Critical \\
\hline 19. Contract management & 48 & 149 & 244 & 181 & 19 & 1897 & 0.592 & 19 & Average Critical \\
\hline 20. Project team planning & 27 & 199 & 238 & 139 & 38 & 1885 & 0.588 & 20 & Average Critical \\
\hline \multicolumn{7}{|c|}{ Reasons Related to Poor Quality of Construction (PQC) } & 0.600 & 3 & Average Critical \\
\hline 1. Proper machinery & 30 & 90 & 191 & 257 & 73 & 2176 & 0.679 & 1 & Very Critical \\
\hline 2. Unskilled labor & 71 & 266 & 185 & 79 & 40 & 1674 & 0.522 & 2 & Average Critical \\
\hline 3. Low grade materials & 83 & 276 & 178 & 73 & 31 & 1616 & 0.504 & 3 & Average Critical \\
\hline 4. Laboratory passed materials & 28 & 75 & 172 & 280 & 86 & 2244 & 0.500 & 4 & Average Critical \\
\hline 5. Materials purchased certified suppliers & 29 & 75 & 164 & 291 & 82 & 2245 & 0.500 & 5 & Average Critical \\
\hline 6. Low grade machinery & 86 & 280 & 182 & 68 & 25 & 1589 & 0.496 & 6 & Average Critical \\
\hline 7. Materials quality check & 88 & 280 & 177 & 69 & 27 & 1590 & 0.496 & 7 & Average Critical \\
\hline 8. Quality management system & 24 & 77 & 166 & 286 & 88 & 2260 & 0.495 & 8 & Average Critical \\
\hline
\end{tabular}


(ii) Reasons for Project Cost Increasing

The first most significant factor is project cost increasing in real estate residential projects before it becomes successful. Under this factor, item cost variations is there for materials and equipments used for construction time to time. Table 4 shows that respondents ranked the materials price fluctuating, cost of machinery always fluctuating, and transportation cost fluctuating as first, second, and third of the most influential cause $(0.768,0.761$, and 0.755 : very critical) responsible for project cost increasing among the twenty items respectively. Followed by machinery maintenance cost as fourth, labor cost fluctuating as fifth, and interest rates by bankers as sixth $(0.745,0.744$, and 0.728 : very critical). These results agree with the findings of several researches conducted in different countries to evaluate the most significant causes of project cost overruns as shown in Appendix-A.

(iii) Reasons related to Poor Quality of Construction

The third significant factor is poor quality of construction in real estate residential house projects. In Table 4, item causing poor quality of construction is due to proper machinery were not used while construction of real estate housing projects is ranked as first (0.679: very critical) followed by unskilled labor used for construction work as second, and low grade materials used in construction of real estate residential housing projects as third of the most influential cause $(0.522$, 0.504: average critical). Followed by construction materials used which is not passed through laboratory quality tests as fourth, materials are purchased from uncertified suppliers as fifth, and low grade machinery used for construction works as sixth $(0.500,0.500$, and 0.496 : average critical). These results agree with the findings of several researches conducted in different countries to evaluate the most significant causes of project cost overruns as shown in Appendix-A.

Table 4 revealed that among all the three factors related to real estate projects to be successful, project cost increasing is found to be very critical factor (0.680), delays in project completion is found to be second most very critical factor (0.627), and third factor is poor quality in construction of real estate projects $(0.600)$.

\section{CONCLUSION}

To make real estate projects to be successful there are many obstacles especially in developing countries like Ethiopia. In this research study three factors viz., delay in construction, project cost increasing, and poor quality of construction in real estate sector has been studied. All three hypotheses stated were rejected and reported that there was no strong positive relationship with project success. Cost increasing factor time to time due to many reasons was found to be the largest obstacles to the real estate construction projects and secondly, delay in construction factor is also contributing to real estate projects to be successful in developing country like Ethiopia. It can be concluded that materials price fluctuating, cost of machinery fluctuating, transportation cost fluctuating, materials and equipments cost variations, lack of foreign currency exchange, and proper machinery were not used for construction were most influential causes (very critical) which become obstacles for real estate projects to be successful in Ethiopia.

Appendix-A: List of Critical Success, Time, Cost, and Quality Factors for Project Success

Critical Success Factors: Radujkovic \& Sjekavica (2017); Meng (2012); Pinto, Slevin, \& English (2009); Toor \& Ogunlana (2009); Toor \& Ogunlana (2008); Alaghbari. Kadir, Salim, \& Ernawati (2007); Sambasivan \& Soon (2007); Andersen, Jessen, Birchall, \& Money (2006); CIDB Malaysia (2006); Kong \& Jason (2006); Fortune \& White (2006); Low \& Chuan (2006); Eriksson (2006); Dainty, Bryman, Price, Greasley, Soetanto, \& King (2005); Lim (2005); Narayanan \& Lai (2005); Nguyen, Ogunlana, \& Lan (2004); Takim, Akintoye, \& Kelly (2004); Belout \& Gauvreau (2004); Kadefors (2004); Cheung, Ng, Wong, \& Suen (2003); Walker \& Hampson (2003); Nicolini (2002); Cooke-Davies (2002); Hartman (2002); Akintoye (2000); Chua, Kog, \& Loh (1999); Dissanayaka \& Kumaraswamy (1999); Kumaraswamy \& Chan (1999); Lim \& Mohamed (1999); Pinto \& Slevin (1988); Walker (1997); Songer \& Molenaar (1997); Chan \& Kumaraswamy (1996); Munns \& Bjeirmi (1996); Belassi \& Tukel (1996); Mayer, Davis, \& Schoorman (1995); Walker (1995); Munns (1995); Sanvido, Grobler, Parfitt, Guvenis, \& Coyle (1992)

Time Overrun: Aziz (2013); Gunduz, Nielsen, \& Ozdemir (2013); Mahamid (2013); Murray \& Seif (2013); Nawaz, Shareef, \& Ikram (2013); Pai \& Bharath (2013); Danso \& Antwi (2012); Modupe, Emmanuel, Agnes, \& Bamidele (2012); Abedi, Fathi, \& Mohammad (2011); Apolot, Alinaitwe, \& Tindiwensi (2011); Hamzah, Khoiry, Arshada, Tawil, \& Che-Ani (2011); Mahamid (2011); Fugar \& Agyakwah-Baah (2010); Yang \& Wei (2010); Al-Kharashi \& Skitmore (2009); Enshassi, AlNajjar, \& Kumaraswamy (2009); Kaliba, Muya, \& Mumba (2009); Luu, Kim, Van Tuan, \& Ogunlana (2009); El-razek, Bassioni, \& Mobarak (2008); Le-Hoai, Lee, \& Lee (2008); Sweis, Sweis, Abu Hammad, \& Shboul (2008); Alaghbari, Kadir, \& Salim (2007); Moura, Teixeira, \& Pires (2007); Sambasivan \& Soon (2007); Assaf \& Al-Hejji (2006); Omoregie \& Radford (2006); Alwi \& Hampson (2003); Odeh \& Battaineh (2002); Ogunlana, Promkuntong, \& Jearkjirm (1996); Assaf, AI-Khalil, \& AI-Hazm (1995)

Source: Author's literature review work 
Appendix-A: List of Critical Success, Time, Cost, and Quality Factors for Project Success (Continued)

Cost Overruns: Niazi \& Painting (2017); Senouci, Ismail, \& Eldin (2016); Shah, (2016); Muhammada, Keyvanfara, Majida, Shafaghata, Maganab, Lawanc, \& Balubaida (2015); Roslan, Zainun, \& Memon, (2015); Cheng (2014); Jamaludin, Mohammad, \& Ahmad (2014); Memon, Rahman, Abdullah, \& Azis (2014); Rosenfeld (2014); Roslan, Zainun, \& Memon (2014); Sharma \& Goyal (2014); Doloi (2013); Ismail, Rahman, \& Memon (2013); Memon, Rahman, \& Karim (2013); Rahman, Memon, \& Karim (2013); Shanmugapriya \& Subramanian (2013); Memon Rahman, \& Azi (2012); Amu \& Adesanya (2011); Apolot, Alinaitwe, \& Tindiwensi (2011); Abdullah, Rahman, \& Azis (2010); Ali \& Kamaruzzaman (2010); Ameh, Soyingbe, \& Odusami (2010); Bhargava, Anastasopoulos, Labi, Sinha, \& Mannering (2010); Cantarelli, Flyvbjerg, Molin, \& Wee (2010); Memon, Rahman, Abdullah, \& Abdu (2010); The Swedish National Audit Office (2010); Enshassi, Al-Najjar, \& Kumaraswamy (2009); Kaliba, Muya, \& Mumba (2009); Mosey (2009); Siemiatycki, (2009); Azhar, Farooqui, \& Ahmed (2008); Eshofonie \& Patience (2008); Le-Hoai, Lee \& Lee (2008); Harisaweni (2007); Moura, Teixeira, \& Pires (2007); Oladapo (2007); Omoregie \& Radford (2006); Koushki, Al-Rashid, \& Kartam (2005); Long, Ogunlana, Quang, \& Lam, (2004); Odeck, (2004); Bordat, McCullouch, \& Sinha (2004); Flyvbjerg, Holm, \& Buhl (2003); Frimpong, Oluwoye, \& Crawford (2003); Jackson (2002); Olujide \& Owosagba (2001); Mansfield, Ugwu, \& Doran (1994); Jahren \& Ashe (1990); Morris (1990); Okpala \& Aniekwu (1988); Kaming, Olomolaiye, Holt, \& Harris (1997)

Project Cost and Time Control: Gunduz, Nielsen, \& Ozdemir (2013); Murray \& Seif (2013); Nawaz, Shareef, \& Ikram (2013); Akinsiku \& Akinsulire (2012); Danso \& Antwi (2012); Abdullah, Azis, \& Rahman (2011); Apolot, Alinaitwe, \& Tindiwensi (2011); Abdullah, Rahman, \& Azis (2010); Ali \& Kamaruzzaman (2010); Ameh, Soyingbe, \& Odusami (2010); Creedy, Skitmore, \& Wong (2010); Fugar \& Agyakwah-Baah (2010); Memon, Rahman, Abdullah \& Asmi (2010); Yang \& Wei (2010); Olawale \& Sun (2010); Abdullah, Rahman, Azis, Tun, \& Onn (2009); Al-Kharashi \& Skitmore (2009); Enshassi, Al-Najjar, \& Kumaraswamy (2009); Kaliba, Muya, \& Mumba (2009); Azhar, Farooqui, \& Ahmed (2008); Latif, Abidin, \& Trigunarsyah (2008); Le-Hoai, Lee, \& Lee (2008); Sweis, Sweis, Abu Hammad, \& Shboul (2008); Alaghbari, Kadir, \& Salim (2007); Sambasivan \& Soon (2007); Aibinu \& Odeyinka (2006); Lo, Fung, \& Tung (2006); Omoregie \& Radford (2006); Iyer \& Jha (2005); Koushki, Al-Rashid, \& Kartam (2005); Lee et al (2005); Long, Ogunlana, Quang, \& Lam (2004); Alwi \& Hampson (2003); Baloi \& Price (2003); Flyvbjerg, Holm, \& Buhl (2003); Aibinu \& Jagboro (2002); Chang \& Asce (2002); Chang (2002); Odeh \& Battaineh (2002); Sonuga (2002); Al-Momani (2000); Kuruooglu \& Ergen (2000); Faniran (1999); Egbu (1998); Kumaraswamy \& Chan (1998); Yogeswaran, Kumaraswamy, \& Miller (1998); Chan \& Kumaraswamy (1997); Kaming, Olomolaiye, Holt, \& Harris (1997); Ogunlana, Promkuntong \& Jearkjirm (1996); Assaf, AlKhaliil, \& Al-Hazmi (1995); Mansfield, Ugwu, \& Doran (1994); Dlakwa \& Cuplin (1990); Morris (1990); Arditi, Akan, \& Gurdamar (1985)

Delays: Maues, Santana, Santos, Neves, Duarte (2017); Santoso \& Soeng (2016); Senouci, Ismail, \& Eldin (2016); Shah, (2016); Owolabi, Amusan, Oloke, Olusanya, TunjiOlayeni, Owolabi, \& Omuh (2014); Aziz (2013); Sunjka \& Jacob (2013); Kazaz, Ulubeyli, \& Tuncbilekli (2012); Haseeb, Xinhai-Lu, Bibi, Maloof-ud-Dyian, \& Rabbani (2011); Orangi, Palaneeswaran, \& Wilson (2011); Fugar \& Agyakwah-Baah (2010); Abd El-Razek, Bassioni, \& Mobarak (2008); Le-Hoai, Lee, \& Lee (2008); Sambasivan \& Soon (2007); Sweis, Sweis, Abu Hammad, \& Shboul (2008); Acharya, Lee, Kim, \& Lee, (2006); Aibinu (2006); Assaf \& Al-Hejji (2006); Faridi (2006); Lo (2006); Koushki (2005); Frimpong (2003); Odeh \& Battaineh (2002); Al-Momani (2000); Al-Khal (1999); Mezher \& Tawil (1998); Odeyinka \& Yusif (1997); Songer \& Molenaar (1997); Ogunlana, Prokuntong, \& Jearkjirm (1996); Assaf, Al-Khaliil, \& Al-Hazmi (1995)

Quality related Problems: El-Saboni, Aouad, \& Sabouni (2009); Thomas \& Fernandez, (2008); Ahadzie, Proverbs, \& Olomolaiye (2007); Kerzner (2006); Rose (2005); Belout \& Gauvreau (2004); Chan \& Chan (2004); Collins \& Baccarini (2004); Hughes, Tippett, \& Thomas (2004); Dvir, Raz, \& Shenhar (2003); Westerveld (2003); Young (2003); Cooke-Davies (2002); White \& Fortune (2002); Armstrong (2001); Chua, Kog, \& Loh (1999); Lim \& Mohamed (1999); Linberg (1999); Munns \& Bjeirmi (1996); Paulk, Weber, Curtis, \& Chrissis (1994); Freeman \& Beale (1992); Wit (1988); Ashley, Lurie, \& Jaselskis (1987); Ashley (1986); Slevin \& Pinto (1986)

Source: Author's literature review work

\section{REFERENCES}

[1] Abd El-Razek, M., Bassioni, H., \& Mobarak, A. (2008). Causes of delay in building construction projects in Egypt. Journal of Construction Engineering and Management, 134(11), 831-841.

[2] Abdullah, M.R., Azis, A.A.A., \& Rahman, I.A. (2011). Potential effects on large MARA construction projects due to construction delay. International Journal of Integrated Engineering, 1(2), 53-62.

[3] Abdullah, M.R., Rahman, I.A., \& Azis, A.A.A. (2010). Causes of delay in MARA management procurement construction projects. Journal of Surveying, Construction, and Property, 1(1), 123-138.

[4] Abdullah, M.R., Rahman, I.A., Azis, A.A.A., Tun, U., \& Onn, H. (2009). Delay in large MARA construction projects based on project. In Proceedings of MUCEET 2009 Malaysian Technical Universities Conference on Engineering and Technology, June 20-22, MS Garden, Kuantan, Pahang, Malaysia, 9-13.

[5] Abedi, M., Fathi, M. S., \& Mohammad, M.F. (2011). Major causes of construction delays under client category and contractor category. The First Iranian Students Scientific Conference in Malaysia, 9 \& 10 April, UPM, Malaysia.

[6] Acharya, N.K., Lee, Y.D., Kim, S.Y., \& Lee, J.C. (2006). Analysis of construction delay factor: A Korean perspective. Proceedings: The 7th Asia Pacific Industrial Engineering and Management Systems Conference. Bangkok, Thailand.

[7] Ahadzie, D.K., Proverbs, D.G., \& Olomolaiye, P.O. (2007). Critical success criteria for mass house building projects in developing countries. International Journal of Project Management, 26, 675-687. 
[8] Aibinu, A. \& Jagboro, G. (2002). The effects of construction delays on project delivery in Nigerian construction industry. International Journal of Project Management, 20(8), 593-599.

[9] Aibinu, A.A. \& Odeyinka, H.A. (2006). Construction delays and their causative factors in Nigeria. Journal of Construction Engineering and Management, 132(7), 667-677.

[10] Aibinu, A.A. (2006). The relationship between distribution of control, fairness and potential for dispute in the claims handling process. Construction Management and Economics, 24(1), 45-54.

[11] Akinsiku, O.E. \& Akinsulire, A. (2012). Stakeholders' perception of the causes and effects of construction delays on project delivery. Journal of Construction Engineering and Project Management, 2(4), 25-31.

[12] Akintoye, A. (2000) Analysis of factors influencing project cost estimating practice. Construction Management and Economics, 18, 77-89.

[13] Alaghbari. W., Kadir, M.R.A., Salim, A., \& Ernawati (2007). The significant factors causing delay of building construction projects in Malaysia. Engineering, Construction and Architectural Management, 14(2), 192-206.

[14] Al-Hazim, N., Salem, Z.A., \& Ahmad, H. (2017). Delay and cost overrun in infrastructure projects in Jordan. 7th International Conference on Engineering, Project, and Production Management, Procedia Engineering, 182, 18-24.

[15] Ali, A.S. \& Kamaruzzaman, S.N. (2010). Cost performance for building construction projects in Klang valley. Journal of Building Performance, 1(1), 10-118.

[16] Al-Khalil, M.I. \& Al-Ghafly, M.A. (1999). Important causes of delay in public utility projects in Saudi Arabia. Construction Management and Economics, 17(5), 647-655.

[17] Al-Kharashe \& Skitmore, M. (2009). Causes of delay in Saudi Arabia public sector construction project. Journal of Construction Management and Economics, 27, 1-3.

[18] Al-Momani, A.H. (2000). Construction delay: A quantitative analysisl. International Journal of Project Management, 18(1), 51-59.

[19] Alwi, S. \& Hampson, K. (2003). Identifying the important causes of delays in building construction projects. In Proceedings The 9th East Asia-Pacific Conference on Structural Engineering and Construction, Bali, Indonesia.

[20] Alzahrani, J. \& Emsley, M. (2013). The impact of contractors' attributes on construction project success: A post construction evaluation. International Journal of Project Management, 31(2), 313-322.

[21] Ameh, O.J., Soyingbe, A.A., \& Odusami, K.T. (2010). Significant factors causing cost overruns in telecommunication projects in Nigeria. Journal of Construction in Developing Countries, 15(2), 49-67

[22] Amu, O.O. \& Adesanya, D.A. (2011). Mathematical expression for explaining project delays in Southwestern Nigeria. Singapore Journal of Scientific Research, 1(1), 59-67.

[23] Anbari, F.T. (1985). A systems approach to project evaluation. Project Management Journal, 16(3), 21-26.

[24] Anbari, F.T. (2010). Distance education in project management. Paper presented at PMI Global Congress 2010-North America, Washington, DC. Newtown Square, PA: Project Management Institute.

[25] Andersen, E.S., Jessen, S.A., Birchall, D., \& Money, A.H. (2006). Exploring project success. Baltic Journal of Management, 1(2), $127-147$.

[26] Apolot, R., Alinaitwe, H., \& D. Tindiwensi (2011). An investigation into the causes of delay and cost overrun in Uganda's public sector construction projects. Second International Conference on Advances in Engineering and Technology, 305-311.

[27] Arditi, D., Akan, G., \& Gurdamar, S. (1985). Cost overruns in public projects. International Journal of Project Management, 3(4), $218-224$.

[28] Armstrong, S. (2001). Engineering and Product Development Management, Cambridge University Press, Cambridge

[29] Ashley, D.B. (1986). New trends in risk management. Internet's 10th International Expert Seminar on New Approaches in Project Management, Zurich.

[30] Ashley, D.B., Lurie, C.S., \& Jaselskis, E.J. (1987). Determinants of construction project success. Project Management Journal, 18(2), 69-79

[31] Assaf, S.A. \& Al-Hejji, S. (2006). Causes of delay in large construction projects. International Journal of Project Management, $24(4), 349-357$.

[32] Assaf, S.A., Al- Khaliil, M., \& Al-Hazmi, M. (1995). Causes of delay in large building construction projects. Journal of Management in Engineering, 11(2), 45-50.

[33] Azhar, N., Farooqui, R.U., \& Ahmed, S.M. (2008). Cost overrun factors in construction industry of Pakistan. First International Conference on Construction In Developing Countries (ICCIDC-I) Advancing and Integrating Construction Education, Research \& Practice, August 4-5, 2008, Karachi, Pakistan, 499-508.

[34] Aziz, R.F. (2013). Factors causing cost variation for constructing wastewater projects in Egypt. Alexandria Engineering Journal, 52, 51-66.

[35] Baloi, D. \& Price, A. (2003). Modelling global risk factors affecting construction cost performance. International Journal of Project Management, 21(4), 261-269.

[36] Barrie \& Paulson. (1992). Professional construction management. USA: Mc Graw Hill.

[37] Belassi, W. \& Tukel, O.I. (1996). A new framework for determining critical success/failure factors in projects. International Journal of Project Management, 14(3), 141-151.

[38] Belout, A. \& Gauvreau, C. (2004). Factors influencing project success: the impact of human resource management. International Journal of Project Management, 22, 1-11

[39] Bhargava, A., Anastasopoulos, P.C., Labi, S., \& Sinha, K.C., \& Mannering, F.L. (2010). Three-stage least-squares analysis of time and cost overruns in construction contracts. Journal of construction Engineering and Management, 136(11), 1207-1218.

[40] Bhirud, A.N. \& Vasant, K.G. (2015). Analysis of critical success factors for application of public private partnership in real estate. International Journal on Recent and Innovation Trends in Computing and Communication, 3(2), 757-760.

[41] Bordat, C., McCullouch, B., \& Sinha, K. (2004). An analysis of cost overruns and time delays of INDOT projects. Indiana, USA: Joint Transportation Research Program.

[42] BusinessDictionary.com. What is a project? definition and meaning.

[43] Cantarelli, C.C., Flyvbjerg, B., Molin, E.J.E., \& Wee, B.V. (2010). Cost overruns in large-scale transportation infrastructure projects: Explanations and their theoretical embeddedness. European Journal of Transport and Infrastructure Research, 10(1), 5-18.

[44] Chai, C.S. \& Yusof, A.M. (March 2015). SEM Approach: Reclassifying housing delay in Malaysian housing industry. Journal of Economics, Business and Management, 3(3), 364-369.

[45] Chan, A. \& Chan, A. (2004). Key performance indicators for measuring construction success. Benchmarking: An International Journal, 11(2), 203221.

[46] Chan, D.W.M. \& Kumaraswamy, M.M. (1996). An evaluation of construction time performance in the building industry. Building and Environment, 31(6), 569-578.

[47] Chan, D.W.M. \& Kumaraswamy, M.M. (1997). A comparative study of causes of time overruns in Hong Kong construction projects. International Journal of Project Management, 15(1), 55-63.

[48] Chandra, P. (2017). Projects: Planning, analysis, selection, financing, implementation, and review (8th ed.). McGraw Hill Education (India) Private Limited, New Delhi, India.

[49] Chang, A.S. \& Asce, M. (2002). Reasons for cost and schedule increase for engineering design projects. Jounal of Management in Engineering, 18(1), 29-36. 
[50] Cheng, Y.M. (2014) An exploration into cost-influencing factors on construction projects. International Journal of Project Management, 32, 850-860.

[51] Cheong, Y.Y. \& Mustaffa, N.E. (2017). Critical success factors for malaysian construction projects: An investigative review. International Journal of Built Environment and Sustainability, 4(2), 93-104.

[52] Cheung S.O., Ng, S.T., Wong S.P., \& Suen H. (2003). Behavioural aspects of construction partnering. International Journal of Project Management, 21(5), 333-343.

[53] Cheung, S.O., Suen, H.C.H., \& Cheung, K.K.W. (2004). PPMS: A web based construction project performance monitoring system. Automation Construction, 13(3), 361-366.

[54] Chua, D.K.H., Kog, Y.C., \& Loh, P.K. (1999). Critical success factors for different project objectives. Journal of Construction Engineering and Management, 125(3), 142-150.

[55] CIDB Malaysia (2006). Construction industry master plan (2006-2015): Construction industry development board (CIDB). Kuala Lumpur.

[56] Collins, A. \& Baccarini, D. (2004). Project Success-A survey. Journal of Construction Research, 5(2), 211-231

[57] Cooke-Davies, T. (2002). The 'real' successfactors on projects., International Journal of Project Management, 20(3), $185-190$.

[58] Creedy, G.D., Skitmore, M., \& Wong, J.K.W. (2010). An evaluation of the risk factors leading to cost overrun in the delivery of highway. Journal of Construction Engineering and Management, 136(5), 528-536.

[59] Dainty, A.R.J., Bryman, A., Price, A.D.F., Greasley, K., Soetanto, R., \& King, N. (2005). Project affinity: The role of emotional attachment in construction projects. Construction Management and Economics, 23(3), 241-244.

[60] Danso, H. \& Antwi, J.K. (2012). Evaluation of the factors influencing time and cost overruns in telecom tower construction in Ghana. Civil and Environmental Research, 2(6), 15-25.

[61] Desai, M.C. \& Desale, S.V. (May 2013). Study factors affecting of delay in residential construction projects for Nashik city. International Journal of Latest Trends in Engineering and Technology, 2(3), 115-124.

[62] Dissanayaka, S.M. \& Kumaraswamy, M. M. (1999). Evaluation of factors affecting time and cost performance in Hong Kong building projects. Engineering, Construction and Architectural Management, 6(3), 287-298.

[63] Dlakwa, M.M. \& Culpin, M.F. (1990). Reasons for overrun in public sector construction projects in Nigeria. International Journal of Project Management, 8(4), 237-240.

[64] Doloi, H. (2013). Cost overruns and failure in project management: Understanding the roles of key stakeholders in construction projects. Journal of Construction Engineering Management, 139(3), 267-279

[65] Dvir, D., Raz, T., \& Shenhar, A. (2003). An empirical analysis of the relationship between project planning and project success. International Journal of Project Management, 21, 89-95.

[66] Egbu, C., Young, B., \& Torrance, V. (1998). Planning and control processes and techniques for refurbishment management. Construction Management and Economics, 16, 315-325.

[67] El-Saboni, M. Aouad, G., \& Sabouni, A. (2009). Electronic communication systems effects on the success of construction projects in United Arab. Advanced Engineering Informatics, 23(1), 130-138.

[68] Enshassi, A., Al-Najjar, J., \& Kumaraswamy, M. (2009). Delays and cost overruns in the construction projects in the Gaza strip. Journal of Financial Management of Property and Construction, 14(2), 126-151.

[69] Eriksson, P.E. (2006). Procurement and governance management: Development of a conceptual procurement model based on different types of control. International Review of Management Studies, 17(1), 30-49.

[70] Eshofonie, B. \& Patience, F. (2008). Factors affecting cost of construction in Nigeria. Department of Building University of Lagos, Akoka, Lagos Masters in Construction Management Thesis.

[71] Faniran, O. (1999). The role of construction project planning in improving project delivery in developing countries: Case study of the Nigerian construction industry. 2nd International Conference on Construction Industry Development, and 1st Conference of CIB TG 29 on Construction in Developing Countries, 27-29 October 1999, The Pan Pacific, Singapore.

[72] Faridi, A.S. \& El-Sayegh, S.M. (2006). Significant factors causing delay in the UAE construction industry. Construction Management Economics, 24(11), 67-76.

[73] Flyvbjerg, B., Holm, M., \& Buhl, S. (2003). How common and how large are cost overruns in transport infrastructure projects? Transport Reviews, 23(1), 71-88.

[74] Fortune, J. \& White, D. (2006). Framing of project critical success factors by a systems model. International Journal of Project Management, 24(1), 53-65.

[75] Freeman, M. \& Beale, P. (1992). Measuring project success, Project Management Journal, 23(1), 8-17.

[76] Frimpong, Y., Oluwoye, J., \& Crawford, L. (2003). Causes of delay and cost overruns in construction of groundwater projects in a developing country: Ghana as a case study. International Journal of Project Management, 21(5), 321-326.

[77] Fugar, F.D.K., \& Agyakwah-Baah, A.B. (2010). Delays in building construction projects in Ghana. Australasian Journal of Construction Economics and Building, 10, 103-116.

[78] Gündüz, M., Nielsen, Y., \& Özdemir, M. (2013). Quantification of delay factors by using relative importance index (RII) method for construction projects in Turkey. Journal of Management in Engineering, 29(2), 133-139.

[79] Hamzah, N., Khoiry, M.A., Arshada I., Tawil, N.M., \& Che Ani, A.I. (2011). Cause of construction delay-Theoretical framework. 2nd International Building Control Conference 2011, Procedia Engineering, 20, 490-495.

[80] Harisaweni, (2007). The framework for minimizing construction time and cost overruns in paddmg and Pekanbam Indonesia. Masters Thesis, Universiti Teknologi Malaysia.

[81] Hartman, F.T. (2002). The role of trust in project management. In Slevin, D.P., Cleland, D.I., \& Pinto, J.K. (eds), The frontiers of project management research, Project Management Institute, Newtown Square, PA, 225-235.

[82] Haseeb, M., Xinhai-Lu, Bibi, A., Maloof-ud-Dyian, \& Rabbani, W. (2011). Problems of projects and effects of delays in the construction industry of Pakistan. Australian Journal of Business and Management Research, 1, 41-50.

[83] Heerkens, G.R. (2012). Project management. McGraw-Hill, New York.

[84] http://www.ddegjust.ac.in/studymaterial/mba/fm-405.pdf

[85] Hughes, S.W. Tippett, D.D., \& Thomas, W.K. (2004). Measuring project success in the construction industry. Engineering Management Journal, 16(3), 31- 37 .

[86] Ismail, I., Rahman, I.A., \& Memon, A.H. (2013). Study of factors causing time and cost overrun throughout life cycle of construction project. Proceedings of Malaysian Technical Universities Conference on Engineering \& Technology (MUCET), 3-4 December, Kuantan, Pahang, 1-7.

[87] Iyer, K. \& Jha, K. (2005). Factors affecting cost performance evidence from Indian construction projects. International Journal of Project Management, 23(4), 283-295.

[88] Iyer, K.C. (1996). Identification and evaluation of dispute-prone clauses in Indian construction contracts. Doctoral Thesis, Indian Institute of Technology, Madras, India.

[89] Jackson, S. (2002) Project cost overruns and risk management. In Greenwood, D. (Ed.) Proceesdings of Association of Researchers in Construction Management 18th Annual ARCOM Conference, Newcastle, Northumber University, UK. 
[90] Jahren, C.T. \& Ashe, A.M. (1990). Predictors of cost-overrun rates. Journal of Construction Engineering and Management, 116(3), 548-552.

[91] Jamaludin, S.Z.H.S, Mohammad, M.F., \& Ahmad, K. (2014). Enhancing the quality of construction environment by minimizing the cost variance. Procedia-Social and Behavioral Sciences, 153, 70-78.

[92] Kadefors, A. (2004). Trust in project relationships-inside the black box. International Journal of Project Management, $22(3), 175-182$.

[93] Kaliba, C., Muya, M., \& Mumba, K. (2009). Cost escalation and schedule delays in road construction projects in Zambia. International Journal of Project Management, 27, 522-531.

[94] Kaming, P., Olomolaiye, P., Holt, G., \& Harris, F. (1997). Factors influencing construction time and cost overruns on high-rise projects in Indonesia. Construction Management and Economics, 15(1), 83-94.

[95] Kazaz, A., Ulubeyli, S., \& Tuncbilekli, N.A. (2012). Causes of delays in construction projects in Turkey. Journal of Civil Engineering and Management, 18, 426-435.

[96] Kerzner, H. (2006). Project management best practices: Achieving global excellence. John Wiley, New York.

[97] Kong, A.T. \& Gray, J. (2006). Problems with traditional procurement in the Malaysian construction industry-A Survey. In Runeson, G.A.B., Rick, (Ed.), Australasian Universities Building Educators Association Annual Conference, University of Technology, Sydney. Australasian Universities Building Educators Association, Sydney, 1-21.

[98] Kothari, C.R. \& Garg, G. (2014). Research methodology: Methods and techniques (3rd ed.). New Age International (P) Limited, Publishers, New Delhi, India.

[99] Koushki, P., Al-Rashid, K., \& Kartam, N. (2005). Delays and cost increases in the construction of private residential projects in Kuwait. Construction Management and Economics, 23(3), 285-294.

[100] Kumaraswamy, M.M. \& Chan, D.W.M. (1998). Contributors to construction delays. Construction Management and Economics, 16(1), 17-29.

[101] Kumaraswamy, M.M. \& Chan, D.W.M. (1999). Factors facilitating faster construction. Journal of Construction Procurement, 5(2), 88-98.

[102] Kuruooglu, M. \& Ergen, E. (2000). The effects of economic development on project management in developing countries. 2nd International Conference on Construction in Developing Countries: Challenges facing the construction industry in developing countries, $15-17$ November 2000, Gabarone, Botswana.

[103] Larson, W. \& Gray, C.F. (2011). Project management: The managerial process (5th ed.) New York: The McGraw-Hill Companies, Inc.

[104] Latif, Y., Abidin, I., \& Trigunarsyah, B. (2008). Knowledge-based material cost control for building construction project using expert system approach. In Haigh, Richard and Amaratunga, Dilanthi, Eds. Proceedings CIB International Conference on Building Education and Research, $1969-1978$.

[105] Lee S., Thomas, S., Tucker, R., (2005). The relative impacts of selected practices on project cost and schedule. Construction Management and Economics, 23(5), 545-553.

[106] Le-Hoai, L., Lee, Y. D., \& Lee, J. Y. (2008). Delay and cost overruns in Vietnam large construction projects: A comparison with other selected countries. KSCE Journal of Civil Engineering, 12(6), 367-377.

[107] Lim, C.F. (2005). The Malaysian construction industry: The present dilemmas of unpaid contractors. Master Builders Association of Malaysia (MBAM) Journal, 4th Quarter, 80-82.

[108] Lim, C.S. \& Mohamed, M.Z. (1999). Criteria of project success: an exploratory re-examination. International Journal of Project Management, 17(4), 243-248.

[109] Linberg, K.R. (1999). Software developer perceptions about software project failure: A case study. Journal of System Software, 49 , $177-192$.

[110] Lo, T.Y., Fung, I.W.H., \& Tung, K.C.F. (2006). Construction delays in Hong Kong civil engineering projects. Journal of Construction Engineering and Management, 132, 636-649.

[111] Lock, D. (2001). Project management (8th ed.) Burlington: USA

[112] Long, N.D., Ogunlana, S., Quang, T., \& Lam, K.C. (2004). Large construction projects in developing countries: A case study from Vietnam. International Journal of Project Management, 22(7), 553-561.

[113] Low, S.P. \& Chuan, Q. (2006). Environmental factors and work performance of project managers in construction industry. International Journal of Project Management, 24(1), 24-37.

[114] Luu, V.T., Kim, S.Y., Van Tuan, N., \& Ogunlana, S.O. (2009). Quantifying schedule risk in construction projects using Bayesian belief networks. International Journal of Project Management, 27(1), 39-50.

[115] Mahamid, I. (2011). Risk matrix for factors affecting time delay in road construction projects: Owners' perspective. Engineering, Construction and Architectural Management, 18(6), 609-617.

[116] Mahamid, I. (2013). Common risks affecting time overrun in road construction projects in Palestine: Contractors' perspective. Australasian Journal of Construction Economics and Building, 13(2), 45-53.

[117] Mansfield, N., Ugwu, O., \& Doran, T. (1994). Causes of delay and cost overruns in Nigerian construction projects. International Journal of Project Management, 12(4), 254-260.

[118] Maues, L.M.F., Santana, W.B., Santos, P.C. dos, Neves, R.M. das, \& Duarte, A.A.A.M. (2017). Construction delays: A case study in the Brazilian Amazon. Ambiente Construído, Porto Alegre, 17(3), 167-181.

[119] Mayer, R.C., Davis, J.H., \& Schoorman, F.D. (1995). An integrative model of organizational trust. The Academy of Management Review, 20(3), 709734.

[120] McNamara, C. (2002). Project management. https://www.scribd.com/document/112182394/Pm-Website

[121] Memon, A.H., Rahman, I.A., \& Azi, A.A.A. (2012). Time and cost performance in construction projects in southern and central regions of Peninsular Malaysia. International Journal of Advances in Applied Sciences, 1(1), 45-52.

[122] Memon, A.H., Rahman, I.A., Abdullah, A.R., \& Abdu, A.A.A. (2010). Factors affecting construction cost in Mara large construction project: Perspective of project management consultant. International Journal of Sustainable Construction Engineering \& Technology, 1(2).

[123] Memon, A.H., Rahman, I.A., Abdullah, M.R., \& Azis, A.A.A. (2014). Factors affecting construction cost performance in project management projects: Case of MARA large projects. International Journal of Civil Engineering and Built Environment, 1(1), 30-35.

[124] Meng, X. (2012). The effect of relationship management on project performance in construction. International Journal of Project Management, 30(2), $188-198$.

[125] Mezher, T.M. \& Tawil, W. (1998). Causes of delays in the construction industry in Lebanon. Engineering Construction and Architectural Management, 5(3), 252-260.

[126] Miller, D. (1991). Handbook of research design and social measurement. Riverside County, CA: Sage

[127] Mir, F.A. \& Pinnington, A.H. (2014). Exploring the value of project management: Linking project management performance and project success. International Journal of Project Management, 32, 202-217.

[128] Modesto, S.T. \& Tichapondwa, S.P. (2009). Successful project management: Insights from distance education practices. 1-134. http://oasis.col.org/handle/11599/454

[129] Modupe, A., Emmanuel, O., Agnes, S., \& Bamidele, M. (2012). Impact of risk on performance of design and build projects in Lagos state, Nigeria. Journal of Civil Engineering and Architecture, 6(9), 1210-1217.

[130] Morris, P.W. \& Hough, G.H. (1987). The anatomy of major projects: A study of the reality of project management. John Wiley and Sons, Chichester.

[131] Morris, S. (1990). Cost and time overruns in public sector projects. Economic and Political Weekly, 25(47), 154-168. 
[132] Mosey, D. (2009). Early contractor involvement in building procurement: Contracts, partnering and project management. UK: Wiley-Blackwell.

[133] Moura, H.P., Teixeira, J.C., \& Pires, B. (2007). Dealing with cost and time in the Portuguese construction industry. Proceedmgs of the CIB World Building Congress on Construction for Development, May 14-17, Cape Town, South Africa, 1252-1265.

[134] Muhammada, N.Z., Keyvanfara, A., Majida, M.Z.A., Shafaghata, A., Maganab, A.M., Lawanc, H., \& Balubaida, S. (2015). Assessment of cost escalation factors for building and civil engineering projects in Nigerian construction industry: A multiple regression approach. Jurnal Teknologi, 74(4), 85-91.

[135] Mukuka, M., Aigbavboa, C., \& Thwala, W. (2015). Effects of construction projects schedule overruns: A case of the Gauteng province, South Africa. 6th International Conference on Applied Human Factors and Ergonomics (AHFE 2015) and the Affiliated Conferences, AHFE 2015, Procedia Manufacturing, 3, 1690-1695.

[136] Muller, R. \& Jugdev, K. (2012). Critical success factors in projects: Pinto, Slevin, and Prescott-the elucidation of project success. International Journal of Managing Projects in Business, 5(4), 757-775.

[137] Munns, A.K. \& Bjeirmi, B.F. (1996). The role of project management in achieving project success. International Journal of Project Management, 14(2), 81-87.

[138] Munns, A.K. (1995). Potential influence of trust on the successful completion of a project. International Journal of Project Management, 13(1), 19-24.

[139] Murray, M. \& Seif, M. (2013). Causes of project delays in Nigerian construction industry. European Journal of Civil Engineering and Architecture, 10, $1-7$.

[140] Naoum, S. (2007). Dissertation research and writing for construction students. Oxford: Butterworth-Heinemann.

[141] Narayanan, S. \& Lai, Y.W. (2005). The causes and consequences of immigrant labour in the construction sector in Malaysia. International Migration, 43(5), 31-57.

[142] Nawaz, T., Shareef, N.A., \& Ikram, A.A. (2013). Cost performance in construction industry of Pakistan. Industrial Engineering Letters, 3(2), $19-34$.

[143] Nguyen, L.D., Ogunlana, S.O., \& Lan, D.T.X. (2004). A study on project success factors in large construction projects in Vietnam. Engineering, Construction and Architectural Management, 11(6), 404-413.

[144] Niazi, G.A. \& Painting, N. (2017). Significant factors causing cost overruns in the construction industry in Afghanistan. 7th International Conference on Engineering, Project, and Production Management, Procedia Engineering, 182, 510-517.

[145] Nicholas, J.M. \& Steyn, H. (2008). Project management for business, engineering, and technology: Principles and practice (3rd ed.). Elsevier, Butterworth-Heinemann, Burlington, USA.

[146] Nicolini, D. (2002). In search of project chemistry. Construction Management and Economics, 20(2), 167-177.

[147] Odeck, J. (2004). Cost overruns in road construction-What are their sizes and determinants?. Transport Policy, 11(1), 43-53.

[148] Odeh, A.M. \& Battaineh, H.T. (2002). Causes of construction delay: Traditional contracts. International Journal of Project Management, 20 (1): 67-73.

[149] Odeyinka, H. \& Yusif, A. (1997). The causes and effects of construction delays on completion cost of housing projects in Nigeria. Journal of Financial Management of Property and Construction, 2, 31-44.

[150] Ogunlana, S., Promkuntong, K., \& Jearkjirm, V. (1996). Construction delays in a fast-growing economy: Comparing Thailand with other economies. International Journal of Project Management, 14(1), 37-45.

[151] Okpala, D.C. \& Aniekwu, A.N. (1988). Causes of high costs of construction in Nigeria. Journal of Construction Engineering Management, 114, 233244.

[152] Oladapo, A.A. (2007). A quantitative assessment of the cost and time impact of variation orders on construction projects. Journal of Engineering, Design and Technology, 5(1), 35-48.

[153] Olawale, Y.A. \& Sun, M. (2010). Cost and time control of construction projects: Inhibiting factors and mitigating measures in practice. Construction Management and Economics, 28(5), 509-526.

[154] Olujide, J.O. \& Owosagba (2001). Management of cost overrun in selected building construction projects in Ilorin. Review Business Finance, 3, 1-8.

[155] Omoregie, A. \& Radford, D. (2006). Infrastructure delays and cost escalation: Causes and effects in Nigeria. Proceeding of Sixth International Postgraduate Research Conference, Netherlands: Delft University of Technology and TNO, 79-93.

[156] Orangi, A., Palaneeswaran, E., \& Wilson, J. (2011). Exploring delays in Victoria-based Astralian pipeline projects. Procedia Engineering, $14,874-881$.

[157] Owolabi, J.D., Amusan, L.M., Oloke, C.O., Olusanya, O., TunjiOlayeni, P., Owolabi, D., \& Omuh, I. (2014). Causes and effect of delay on project construction delivery time. International Journal of Education and Research, 2, 197-208.

[158] Oxford Dictionaries (2016). Compare: Definition of project in English from the Oxford dictionary. English.

[159] Pai, S.K. \& Bharath, J.R. (2013). Analysis of critical causes of delays in Indian infrastructure projects. International Journal of Innovative Research \& Development, 2(3), 251-263.

[160] Paulk, M.C., Weber, C.V., Curtis, B., \& Chrissis, M.B. (1994). Capability maturity model: Guidelines for improving the software process, Longman, Addison-Wesley, Reading, MA.

[161] Pinto, J.K. \& Slevin, D.P. (1987). Critical factors in successful project implementation. IEEE Transactions on Engineering Management, EM-34(1), 22-27.

[162] Pinto, J.K. \& Slevin, D.P. (1988). Critical success factors across the project lifecycle. Project Management Journal, 19(3), 67-75.

[163] Pinto, J.K. \& Slevin, D.P. (1988). Project success: Definitions and measurment techniques. Project Management Journal, 19(1), 67-72.

[164] Pinto, J.K. (2013). Project management: Achieving competitive advantage (3rd ed.). Boston: Pearson.

[165] Pinto, J.K., Slevin, D.P., \& English, B. (2009). Trust in projects: An empirical assessment of owner/contractor relationships. International Journal of Project Management, 27(6), 638-648.

[166] Radujkovic, M. \& Sjekavica, M. (2017). Development of a project management performance enhancement model by analysing risks, changes, and constraints. GRADEVINAR, 69(2), 105-120.

[167] Rahman, I.A., Memon, A.H., \& Karim, A.A.T. (2013). Significant factors causing cost overruns in large construction projects in Malaysia. Journal of Applied Sciences, 13(2), 286-293.

[168] Rahman, I.A., Memon, A.H., \& Karim, A.T.A. (2013). Examining factors affecting budget overrun of construction projects undertaken through management procurement method using PLS-SEM approach. Evaluation of Learning for Performance Improvement International Conference, Malaysia, 25-26 February, Procedia-Social and Behavioral Sciences, 107, 120-128.

[169] Rockart, J.F. (1982). "The changing role of information system executive: A critical success factors perspective. Sloan Management Review, 24(1), 313.

[170] Rose, K. (2005). Project quality management: Why, What and How. J. Ross Publishing, Florida.

[171] Rosenfeld, Y. (2014). Root-cause analysis of construction-cost overruns. Journal of Construction Engineering and Management, 140(1), 1-10.

[172] Roslan, N.N., Zainun, N.Y., \& Memon, A.H. (2014). Measures for controlling time and cost overrun factors during execution stage. International Journal of Construction Technology and Management, 1(1).

[173] Roslan, N.N., Zainun, N.Y., \& Memon, A.H. (2015). Relevancy of factors and mitigation measures in controlling time and cost overrun towards Malaysian environment. Applied Mechanics and Materials, 773774, 1007-1011.

[174] Sambasivan, M. \& Soon, Y.W. (2007). Causes and effects of delays in Malaysian construction industry. International Journal of Project Management, $25,517-526$. 
[175] Santoso, D. \& Soeng, S. (2016). Analyzing delays of road construction projects in Cambodia: Causes and effects. Journal of Management in Engineering, 32(6).

[176] Sanvido, V., Grobler, F., Parfitt, K., Guvenis, M., \& Coyle, M. (1992). Critical success factors for construction projects. Journal of Construction Engineering Management, 118(1), 94-111.

[177] Senouci, A., Ismail, A., \& Eldin, N. (2016). Time delay and cost overrun in Qatari public construction projects. Creative Construction Conference 2016, CCC 2016, 25-28 June 2016, Procedia Engineering, 164, 368-375.

[178] Shah, R.K. (2016). An exploration of causes for delay and cost overruns in construction projects: Case study of Australia, Malaysia \& Ghana. Journal of Advanced College of Engineering and Management, 2, 1-15.

[179] Shanmugapriya, S. \& Subramanian, K. (2013). Investigation of significant factors influencing time and cost overruns in Indian Construction Projects. International Journal of Emerging Technology and Advanced Engineering, 3(10), 734-740.

[180] Sharma, S. \& Goyal, P.K. (2014). Cost overrun factors and project cost risk assessment in construction industry-A state of the art review. International Journal of Civil Engineering, 3(3), 139-154.

[181] Shenhar, A.J. \& Dvir, D. (2007). Project management research-the challenge and opportunity. Project Management Journal, 38(2), 93-99.

[182] Siemiatycki, M. (2009). Academics and auditors comparing perspectives on transportation project cost overruns. Journal of Planning Education and Research, 29(2), 142-156.

[183] Slevin, D.P. \& Pinto, J.K. (1986). The project implementation profile: new tool for project managers. Project Management Journal, $18,57-71$.

[184] Songer, A.D., \& Molenaar, K.R. (1997). Project characteristics for successful public-sector design-build. Journal of Construction Engineering and Management, 123, 34-40.

[185] Sonuga, F., Aliboh, O., \& Oloke, D. (2002). Particular barriers and issues associated with projects in a developing and emerging economy. Case study of some abandoned water and irrigation projects in Nigeria. International Journal of Project Management, 20(8), 611-616.

[186] Sunjka, B.P. \& Jacob, U. (2013). Significant causes and effects of project delays in the Niger delta region. Cape Town: SAIIE25 Proceedings: Stellenbosch, South Africa, SAIIE.

[187] Sweis, G.J., Sweis, R., Abu Hammad, A., \& Shboul, A. (2008). Delays in construction projects: The case of Jordan. International Journal of Project Management, 26(6), 665-674.

[188] Sweis, G.J., Sweis, R., Rumman, M.A., Hussein, R.A., \& Dahiyat, S.E. (2013). Cost overruns in public construction projects: The case of Jordan. Journal of American Science, 9(7s), 134-141.

[189] Takim, R., Akintoye, A., \& Kelly, J. (2004). Analysis of measures of construction project success in Malaysia. Proceedings of the 20th Annual ARCOM Conference in Heriot Watt University, 1-3 September, Association of Researchers in Construction Management, 2, 1123-1133.

[190] The Swedish National Audit Office, 2010. Cost control of large road investments?, Stockholm, Sweden: RiR,25.

[191] Thomas, G. \& Fernandez, W. (2008). Success in IT projects: A matter of definition? International Journal of Project Management, 26, 733-742

[192] Tiong, R. (1992). Critical success factors in winning BOT contracts. Journal of Construction Engineering and Management, 118(2), $217-228$.

[193] Toor, S.R. \& Ogunlana, S.O. (2008). Critical COMs of success in large-scale construction projects: Evidence from Thailand construction industry. International Journal of Project Management, 26(4), 420-430.

[194] Toor, S.R. \& Ogunlana, S.O. (2009). Construction professionals' perception of critical success factors for large-scale construction projects. Construction Innovation: Information, Process, Management, 9(2), 149-167.

[195] Verzuh, E. (2005). The fast forward MBA in project management. New Jersey: John Wiley and Sons, Inc.

[196] Walker, D.H.T. \& Hampson, K. (2003). Procurement strategies-A relationship-based approach, Blackwell Science Ltd, Oxford, UK.

[197] Walker, D.H.T. (1995). An investigation into construction time performance. Construction Management and Economics, $13(3), 263-274$.

[198] Walker, D.H.T. (1997). Choosing an appropriate research methodology. Construction Management and Economics, 15(2), 149-159.

[199] Wanjari, S.P. \& Dobariya, G. (2016). Identifying factors causing cost overrun of the construction projects in India. Sadhana, 41(6), 679-693.

[200] Westerveld, E. (2003). The project excellence model: Linking success criteria and critical success factors. International Journal of Project Management, 21, 411-418.

[201] White, D. \& Fortune, J. (2002). Current practice in project management-an empirical study. International Journal of Project Management, 20 , 1-11.

[202] Wit, Anton de (1988). Measurement of project success. International Journal of Project Management, 6(3),130-192.

[203] Yang, J. \& Wei, P. (2010). Causes of delay in the planning and design phases for construction projects. Journal of Architectural Engineering, 16(2), 80-83.

[204] Yogeswaran, K., Kumaraswamy, M., \& Miller, D. (1998). Claims for extension of time in civil engineering projects. Construction Management and Economics, 16(3), 283-293. 